SECTION 22. Policy. Innovations. Theory, practice and methods.

Aleksandr Mihailovich Tamitskiy

Candidate of political Sciences, Assoc. prof., Northern (Arctic) Federal University named after M.V. Lomonosov, Russia

a.tamitskiy@gmail.com

Ekaterina Nikolaevna Tamitskaya

Assistant, research associate,

Northern (Arctic) Federal University named after M.V. Lomonosov, Russia

nevis2008@,rambler.ru

\title{
RUSSIAN STATE ARCTIC POLICY XX-XXI CENTURIES: PRIORITIES AND PERSPECTIVES
}

\begin{abstract}
The article presents the development of the Russian state policy in the Arctic, explains the present aims and goals of the Russian state policy in the Arctic. The author discusses the problems and perspectives for the Russian state policy in the Arctic in the nearest future.

Key words: Arctic, international relations, Russian state politics, Arctic dimension in the Russian state politics
\end{abstract}

\section{Introduction}

The period between 1990s and 2000s changed the attitude to the Arctic among the actors of international relations. The Arctic territories are extremely important geo-political space, a huge storage of resources (13\% of world petroleum reserves, $30 \%$ of world gas reserves, and other natural resources) and a convenient sea and air route. The Arctic is an issue for border territories and counties (Canada, Denmark, Norway and USA) and it is also important for Germany, China, Japan and other states without Arctic borders. The most influential international organizations EU and NATO are now showing their interest to the Arctic and are coming up with their own suggestions on Arctic legal status. Various political views on Arctic legal status are represented in a great number of declarations and resolutions [1] that are driving international cooperation and political concurrence in the Arctic. Russian Federation is one of the interest states and has the long time experience in providing Arctic policy.

The article is aimed to represent aims, goals, priorities and perspectives of the Russian state politics in the Arctic for the past 20 years. The author is explaining the periods and changes in the Russian state policy to show what kind of issues influenced the Russian political concepts applied to the Arctic policy. The second part of the article is devoted to the contemporary Russian state policy. The author is analyzing the Russian legal documentation, laws and their drafts to represent the contemporary attitude of the Russian state to the Arctic territories and to clarify Russian state political interests in the region.

\section{Building up Russian Arctic policy 1990- 1997}

The Russian Arctic policy past has much to do with the Soviet system. That time Arctic territories we viewed as the storage of resource and area for military purposes. For some time after the collapse of the USSR politicians seemed to forget about Arctic. But it was not so for a long time. The author presents the Russian Arctic policy as a unity of three periods. The first one is called "inertial". Russian state established new bodies to develop and provide its national interests in the Arctic. The interests could be divided into 4 groups:

1. Social and economic development of the northern territories 
2. Improvement of ecology in the North

3. Support of indigenous people of the North

4. Interational cooperation development

First two goals were reached with the help of the State Arctic and Antarctic committee of RSFSR [2] (SAC of RSFSR) that had been established in 1991. Next year the committee changed its name to the Russian state Arctic and Antarctic committee (RSAC) [3] and then to the Interdepartmental Arctic and Antarctic commission (IAC). The IAC was established to coordinate the scientific research, economic and ecological activity in the Arctic (including Spitsbergen) and Antarctic. The commission had also to control the implementation of various Russian legal acts concerning Arctic and Antarctic. The second executive governmental body related to the Arctic was the State Committee of the North. It had been working between 1990 and 2000 on social and economic development of the Russian north.

Indigenous issues became major for the All-Russia Scientific coordination center for complex problems of the North, Arctic and indigenous people [4]. The center was established to provide detailed research of the Arctic areas and its indigenous population. The research contributed to the Russian state policy towards indigenous people of the North. In 1994 the Council of Federation organized Senators from Northern territories into the Committee of the North. Indigenous and local social, resource and cultural interests were provided into the state politics through this committee. The work done by the Committee was represented in a great number of legal acts [5]. The major act is the state law "On foundations of the state regulation social and economic development of the Russian North" [6] - one of the first documents for the Russian Arctic strategy. The clou of the law was protection and support of indigenous rights and culture according to the international laws ratified by Russia. The cultural rights of indigenous people are secured by the Constitution (Articles 68 and 69) also.

Since 1990s Russia had been intensifying its activity and contacts with the Arctic states. Russia became a member of the Council of the Baltic States (1992), Nordic Forum (1992), Barents Euro-Arctic Council (1993), Arctic Council (1996), and Northern Dimension partnership (1999). Security partnership had been also important. In 1994 Russia and Norway hold maneuvers in Troms and Finnmark. During the next ten years there was no military cooperation between these two countries.

After the collapse of the USSR new Russian state changed its attitude to the Arctic policy and had started to open the Russian part of Arctic top the other states. The Arctic became the territory of a dialog instead of "closed military area" or "resource storage". New issues appeared in the Russian Arctic policy: indigenous cultural and resource rights, ecology and sustainable development. New tendencies in the state policy had become visible after the changes in the legal status of the Northern Sea Route. Russian state had stopped to be the only owner of the NSR. The results were rather controversial. On the one hand the NSR became free from the strong soviet political influence. On the other hand private companies were not able to take care about Northern ports, ships and security. Everything seemed to be ruined there [7, p. 39]. It is almost 20 years passed by now but NSR is still ruined. By the 2020 we are now expecting to lose 4 icebreakers and to have only one icebreaker "50 years of Victory" [8]. Facing such a problem "we are planning to get one linear icebreaker in 2017 and one atomic icebreaker in 2019" [9].

After the collapse of the USSR we had been observing the population outflow caused by the economic crash. We lost around 3 million people and are still losing population. The number of population reduced in Chukotka [10, p. 4], Murmansk region and Komi Republic [11]. The greatest outflow was observed among young and well qualified specialists. The population problem is still the major and undecided problem for the northern territories.

Russian Arctic policy 1997-2000 
The second period in the Russian Arctic policy began in 1997 and it was still inertial but in different circumstances. Russia ratified UN Convention on the Law of the Sea that set up 12 miles state border and 200 miles economic border for sea spaces.

Russian government states some more problems for Russian policy [12]:

1. Support of economic activity in the North.

After the collapse of USSR almost all industry and production in the North disappeared. There was a great need in plants, factories, services in the North, because people started to leave there homes due to the lack of jobs and terrible living conditions.

2. Formation of manpower resources for northern territories.

Northern territories required a great number of high qualified specialists to continue the work on resource extraction factories. There was a lack of specialist for various numbers of services also. Living in the North is hard for health and we even had a lack of medical personnel.

3. Addressness of state financial support.

Financial problems in Russia in 1990s made the state to control the way the state paid money.

Economic collapse led to the growth of corruption. Addressness of financial support was very important because it served the needs of people and also helped the state not to waste money. There was a draft "on Arctic zone of Russia" aimed to provide the legal mechanism for the Addressness of financial support for the population of the North [13]. The Russian parliament did not ratify this draft.

4. Facilities for living and working in the North

First of all the State was interested in modernization. It wanted to make the North attractive for living and working.

5. Development of food, oil and gas supply for northern territories

This task was extremely important because there are territories in the Russian North where it is very difficult to live and difficult to get (no shipping possibilities, no roads and hard air access due to the bad weather) so, the developed routs of transportation we needed to provide the local population with all necessary things.

The attempt to implement the Russian state policy in the Arctic had not positive outcomes in theses three years. It had happened because of disconnection of political elites and low financial support of the Arctic territories.

\section{Making Russian Arctic policy 2000-2013}

The third stage of the Russian Arctic policy had begun in 2000. That time Russia started to implement all that had not been done before. The national interests were the major in the home and foreign policy of Russia. On the $24^{\text {th }}$ of March 2000 the Russian government issued instructions № 441-p on grounds for the widening the Russian shelf borders. Russia indented to send the application to the UN and to get a positive response. So, North became visible again. The State decided to improve the situation there as soon as possible "The Concept of National Security of Russian Federation" [14] ratified the same year stated that the government should provide "the mechanism of support for the crisis areas and High North". The President's order "on Strategy of National Security 2020" [15] contains information about importance of Northern borders, development of economy, competitiveness of oil and gas industry, improvement of transport system, information security and military aspects.

In 2001 the government ratified the draft of "Grounds of Russian State policy in the Arctic" - the document on border issues, international cooperation, ecological security and economy. The document is based on the idea that the Arctic is a peaceful territory and there are no security problems there. Russia would rather have peaceful international cooperation in the Arctic then military conflicts. So, Russia would do its own best to contribute to international cooperation and sustainable development of the region. 
This year the President of Russian Federation approved the "Development strategy of the Arctic zone and national security supply". This document is the evidence of Russian activity in the Arctic aimed to provide growing competitiveness of Russia in the region and strengthening its position in the international level.

The long time distance between the ratification of the major legal acts could be the evidence of long-term debates and the absence of coordinate state body. In 2000 State Duma [16] had offered the President a new governmental body on High North and areas equated to the high North. Official establishment of the body called "Council o on the problems of the high North and Arctic under the Russian State Government" (CNARSG) had occurred in 2002 but it was closed 2 years after together with the IAC [17]. Further development of the Arctic territories had been carried out by the Ministry of economic development and the Marine board under the Russian State Government. Everything got clear in Russian Arctic policy. Its focus moved into economic and border issues.

In 2000 Russia carried out an expedition "Arctic 2000". The expedition collected data on underwater mountain ridges Lomonosov and Mendeleev and proved that the ridges were a continuation of the continent. On that grounds Russia demanded the $12 \mathrm{mil}$. km expansion of the boundaries in the Arctic ocean. The UN asked Russia to submit barometric and navigation maps and geological data. A new revised application is expected to be ready by the December 2013 and is going to be sent to the UN in January 2014. In 2000s some more expedition were carried out. They are "Arctic 2007" and every year expeditions "Northern Pole". Nowadays we are widely using the drift-ice research units in the Arctic for environmental and ecological monitoring. In 2013 the environmental research has been carried out by the unit "Northern Pole-40". In 2010 the State initiated the establishment of the Northern (Arctic) Federal University (NAFRU) to support the northern science and to train various specialists for North. The NARFU is carrying out the research and educational project "Arctic floating university". The project is aimed to train young researchers and specialists in the real conditions of the Northern seas.

In 2000s Russian hosted a great number of international forums and meetings on Arctic development. The leaders of the Arctic states often meet on international "Arctic Forum" (Moscow 2010, Arkhangelsk 2011, Salekhard 2013). The Forum contributes to the economic, ecological, cultural development of the Arctic territories and it had become the ground for the further cooperation. One of the most important issues for the international Arctic cooperation is the Northern Sea Route (NSR) and conditions for its international use. New law on NSR 2012 states that the NSR is "the historically formed national route of transportation of the Russian Federation" [18, p. 237] but NSR is widely used for international transportation. In 2010 Arctic transit was around 115.000 tones (45.000 tones - foreign companies), in 2011- 674.000 tones (500. 000 tones - foreign companies), in $2012-1,2$ million tones [19]. The commodity turnover had 10 times growth.

In recent year Russia got back to security issues in the North. Except the marine military operations 2012-2013 [20], Russia participated in common maneuvers with Norway in 2010, in canadian-american maneuvers in 2011 ("Vigilant eagle"), in norwegian-american maneuvers 2004-2012. Security issues influenced the reconstruction of the soviet military infrastructure in the Arctic seas.

International activity of the Russian Federation mostly goes through the Arctic Council and UN. In 2008 Russia together with Denmark, Canada, USA and Norway signed the Ilulissat Declaration and agreed that there was no need to change the mode of Nasr's use and all the cooperation in the North would be done in accordance with the international law. In 2010 Russia and Norway agreed upon the marine delimitation and cooperation in the Barents sea and the Arctic ocean. The agreement accelerated the resource cooperation in the North in favor of two countries involved.

The third stage in the modern Russian Arctic policy was very intensive in comparison with the previous two. On the one hand, Russian policy was opened and welcoming, but on the other 
hand, Russian military forces in the Arctic started to grow again. The situation demonstrates the will of Russia to cooperate and at the same time to defend it s territories and interests. In the past thirteen years Russia defined its priorities in the Arctic as the resource use, expansion of borders and legal security of the NSR. The content of the Russian Arctic policy changed a lot in recent years. In 1990s the policy had been focused on legal grounds for the Arctic development, acceleration of the international cooperation and institutionalization of the Arctic management. In 2000s the policy turned into practical deeds: reconstruction of the Arctic infrastructure, security $f$ the NSR, debates with the UN on border expansion, etc. If one takes a broader look on the Russian Arctic policy, it will be clear that Russian policy is fragmentary and had a lack of strategy. The dramatic situation could be explained by the transition period in Russia and its economic problems but in our opinion it had been caused by the lack of management strategy and free market experience in Russia.

The prospect development of the Russian Arctic policy could be connected with the:

- On-going legal development of the Russian Arctic and adoption of the federal law "On Arctic zone of Russian Federation" and the state social and economic development program 2020;

- Establishment of a coordinate management body on Arctic issues;

- Acceleration of the economic development in the Russian Arctic, development of resource extraction, marine transportation, ecological security and tourism;

- State support of science and education in the Arctic;

- Modernization of marine technologies;

- Ecological law development in accordance to the international legal norms.

The international concurrence in the Arctic is going to develop with the use of political, energy, economic, humanitarian and information influence. Serious problems could be caused by the aspirations for the information control visible now in some foreign states [21]. In this term it is extremely important for Russia to develop Arctic information strategy and include it into the international cooperation strategy. In other words, giving up the development of the balanced Russian Arctic strategy could cause the serious challenges for the Russian Arctic policy in the nearest future.

\section{References:}

1. The Norwegian government's High North strategy, 2006; Arktis i en brydningstid Forslag til strategi for aktiviteter i det arktiske område (Dannmark) 2008; Osnovy gosudarstvennoj politiki Rossijskoj Federacii v Arktike na period do 2020 goda i na dal'nejshuju perspektivu, 2008; National Security Presidential Directive on Arctic Region Policy, 2009 (USA); Canada's northern strategy, 2009; New Building Blocks in the North. The Next Step in the Government's High North Strategy, 2009 (Norway); Suomen arktinen strategia, 2010 ; Sweden's strategy for the Arctic region 2011-2013, 2011; Strategija razvitija Arkticheskoj zony Rossijskoj Federacii i obespechenija nacional'noj bezopasnosti na period do 2020 goda, 2013 (Russia); National strategy for the Arctic region, 2013 (USA.).

2. Postanovlenie Pravitel'stva RSFSR «O Gosudarstvennoj komissii RSFSR po delam Arktiki i Antarktiki» ot 26 dekabrja 1991 g. № 75.

3. Postanovlenie Pravitel'stva RF «Ob utverzhdenii Polozhenija o Gosudarstvennoj komissii Rossijskoj Federacii po delam Arktiki i Antarktiki i personal'nogo sostava Gosudarstvennoj komissii Rossijskoj Federacii po delam Arktiki i Antarktiki» ot 28 marta 1992 g. № 197.

4. Postanovlenie Pravitel'stva RF «O Vserossijskom nauchno-koordinacionnom centre po kompleksnym problemam Severa, Arktiki i zhiznedejatel'nosti malochislennyh narodov Severa Gosudarstvennogo komiteta Rossijskoj Federacii po social'no-jekonomicheskomu razvitiju Severa» ot 22 ijunja 1992 g. № 419. 
5. See: Rasporjazhenie Pravitel'stva RF «O Koncepcii social'no-jekonomicheskogo razvitija rajonov Severa» ot 18 janvarja 1992 g. № 107-r; Postanovlenie SND RF «O social'nojekonomicheskom polozhenii rajonov Severa i priravnennyh k nim mestnostej» ot 21 aprelja 1992 g. № 2707-1 // Vedomosti SND i VS RF. -1992. - № 18. St. 984, etc.

6. Federal'nyj zakon «Ob osnovah gosudarstvennogo regulirovanija social'no jekonomicheskogo razvitija Severa Rossijskoj Federacii» ot 19 ijunja 1996 g. № 78-FZ (utratil silu) // Sobranie zakonodatel'stva RF. - 1996. - № 26. Article. 3030.

7. Jakovlev A., Lebedev G. Kto upravljaet Severnym morskim putem? // Morskoj sbornik. 2010. - № 6.

8. Atomnyj ledokol'nyj flot Rossii $\mathrm{v}$ polnom sostave obespechil provodku korablej Severnogo flota RF. URL: http://neftegaz.ru/news/view/113423 (07.11.2013)

9. Mihajlov A.S. Odin v more ne voin // Rossijskaja gazeta. - 2013. - 23 apr. URL: http://www.rg.ru/2013/04/23/korabli.html (09.11.2013)

10. Matveev A.S. Vosstanovit' i rasshirit' sistemu garantij i kompensacij severjanam // Problemy Severa i Arktiki Rossijskoj Federacii. - 2011. - № 13.

11. Rosstat data (10.07.2014)

12. Postanovlenie Pravitel'stva RF «O reformirovanii sistemy gosudarstvennoj podderzhki rajonov Severa» ot 31 dekabrja 1997 g. № 1664 // Sobranie zakonodatel'stva RF. - 1998. № 2. Article. 256.

13. Postanovlenie SF FS RF «O proekte Federal'nogo zakona «Ob arkticheskoj zone Rossijskoj Federacii» ot 10 ijulja 1998 g. № 323-SF // Sobranie zakonodatel'stva RF. 1998. - № 29. St. 3473; Postanovlenie GD FS RF O proekte Federal'nogo zakona «Ob arkticheskoj zone Rossijskoj Federacii» ot 11 oktjabrja 2000 g. № 689-III GD // Sobranie zakonodatel'stva RF. - 2000. - № 43. St. 4203.

14. Ukaz Prezidenta RF «O Koncepcii nacional'noj bezopasnosti Rossijskoj Federacii» ot 10 janvarja 2000 g. № 24 (utratil silu) // Sobranie zakonodatel'stva RF. - 2000. - № 2. Article 170.

15. Ukaz Prezidenta RF «O Strategii nacional'noj bezopasnosti Rossijskoj Federacii do 2020 goda» ot 12 maja 2009 g. № 537 // Sobranie zakonodatel'stva RF. - 2009. - № 20. Article. 2444

16. Postanovlenie GD FS RF «Ob obespechenii ustojchivogo razvitija rajonov Krajnego Severa i priravnennyh k nim mestnostej» ot 28 ijunja 2000 g. № 504-III GD // Sobranie zakonodatel'stva RF. - 2000. - № 28. Article. 2933.

17. Postanovlenie Pravitel'stva RF «Ob uporjadochenii sostava koordinacionnyh, soveshhatel'nyh, inyh organov i grupp, obrazovannyh Pravitel'stvom Rossijskoj Federacii» ot 16 aprelja 2004 g. № 215 // Sobranie zakonodatel'stva RF. - 2004. - № 17. Article 1658.

18. Article. 14 Federal'nogo zakona «O vnesenii izmenenij v otdel'nye zakonodatel'nye akty Rossijskoj Federacii v chasti gosudarstvennogo regulirovanija torgovogo moreplavanija $\mathrm{v}$ akvatorii Severnogo morskogo puti» // Rossijskaja gazeta. 30.07.2012. № 172 .

19. Fisenko A.I Geopoliticheskie i transportno-jekonomicheskie aspekty razvitija Severnogo morskogo puti v Rossii // Transportnoe delo Rossii. - 2013. - № 4.

20. Weir F. Russian navy returns to Arctic. Permanently. // Christian Science Monitor. URL: http://www.csmonitor.com/World/2013/0916/Russian-Navy-returns-to-Arctic.-Permanently (07.09.2013)

21. Cygichko V.N., Smoljan G.L., Chereshkin D.S. Informacionnoe oruzhie kak geopoliticheskij faktor i instrument silovoj politiki; In-t sistem. analiza RAN. - M.: ISA, 1997. - $31 \mathrm{p}$. 